\title{
The Impact of the COVID-19 Pandemic on Children's Health in Portugal: The Parental Perspective
}

\section{O Impacto da Pandemia COVID-19 na Saúde Infantil em Portugal: O Relato dos Pais}

\author{
Mariana POPPE $\rrbracket^{1}$, Bárbara AGUIAR ${ }^{1}$, Rodrigo SOUSA ${ }^{1}$, Paulo OOM $^{1}$ \\ Acta Med Port 2021 May;34(5):355-361 - https://doi.org/10.20344/amp.14805
}

\section{ABSTRACT}

Introduction: The COVID-19 pandemic poses unprecedented challenges for healthcare services and has led to changes in the usage pattern of the pediatric population. We aimed to describe the impact of COVID-19 on children's health, wellbeing, and access to medical care in Portugal.

Material and Methods: We conducted a cross-sectional study through an anonymous online survey via social media. The collected data refers to a period between the $16^{\text {th }}$ of March and the $17^{\text {th }}$ of May 2020.

Results: We obtained responses to the survey on 19745 children. Of the previously scheduled outpatient consultations, $54.2 \%$ were postponed by healthcare institutions and $21.6 \%$ of planned vaccinations were missed. Parents expressed concerns regarding psychological, social, and physical consequences for their children due to the pandemic.

Discussion: The observed reduction of pediatric emergency department visits and the postponement of outpatient consultations and vaccine administrations are potentially harmful for non-COVID patients. The current pandemic and the imposed social distance might have an important negative impact on the mental health of children.

Conclusion: Further studies are necessary to fully comprehend the outcomes of the decreased access to medical care, as well as the collateral damage for children beyond the clinical aspects of the pandemic. Defining strategies regarding the urge to vaccinate children and not postpone urgent evaluations should be a public health priority.

Keywords: Child; Coronavirus Infections; COVID-19; Health Care Quality, Access, and Evaluation; Health Impact Assessment; Pandemics; Pediatrics

\section{RESUMO}

Introdução: A pandemia COVID-19 constitui um desafio sem precedentes para os serviços de saúde e conduziu a alterações no padrão de utilização dos recursos pela população pediátrica. Procurámos descrever o impacto da pandemia COVID-19 na saúde infantil e no acesso à saúde em Portugal.

Material e Métodos: Realizámos um estudo retrospetivo, recolhendo dados através da aplicação de um inquérito anónimo online nas redes sociais. Os dados referem-se ao período entre 16 de março e 17 de maio de 2020.

Resultados: Obtivemos respostas ao inquérito relativas a 19745 crianças. Da análise às respostas, concluímos que $54,2 \%$ das consultas previamente agendadas foram adiadas pelas instituições de saúde e $21,6 \%$ das vacinações previstas não se realizaram. Os pais expressaram preocupação quanto às consequências psicológicas, sociais e físicas da pandemia nos seus filhos.

Discussão: A reduzida utilização dos serviços de urgência pediátricos, bem como a não realização de consultas e vacinações previamente agendadas é potencialmente lesiva para os doentes não-COVID. A pandemia e o isolamento social imposto poderão causar um impacto negativo na saúde mental das crianças.

Conclusão: Estudos adicionais são necessários para melhor compreender as consequências da diminuição do acesso à saúde, bem como os efeitos psicológicos, sociais e físicos nas crianças. A definição de estratégias para incentivar a vacinação e o não adiamento de avaliações médicas urgentes deveriam ser prioridades de Saúde Pública.

Palavras-chave: Avaliação do Impacto na Saúde; COVID-19; Criança; Infecções por Coronavírus; Pandemia; Pediatria; Qualidade, Acesso e Avaliação da Assistência à Saúde

\section{INTRODUCTION}

The novel coronavirus SARS-CoV-2, causative agent of COVID-19, emerged in December 2019 in the city of Wuhan, China, and has since spread worldwide. The World Health Organization declared COVID-19 to be a pandemic on the $11^{\text {th }}$ of March 2020. ${ }^{1}$ The first case of the disease in Portugal was diagnosed on the $2^{\text {nd }}$ of March and until the end of May there were 1799 children and adolescents $(0-19$ years old) diagnosed with COVID-19. ${ }^{2}$ Most published scientific articles focus on COVID-19 in adults, and, based on current knowledge, the virus seems to cause milder symptoms and have lower fatality rates in the pediatric population. ${ }^{3-8}$

The current pandemic poses new challenges for the healthcare workforce as well as for patients, potentially leading to changes in medical care usage patterns ${ }^{9}$. Concerns have been raised regarding the consequences for non-COVID patients due to decreased access to medical care both in adults ${ }^{10,11}$ as in children, ${ }^{12-14}$ as visits to emergency departments (ED) have dropped significantly.9.12,15-19 Medical resources have been redistributed to meet the needs of this health emergency, with most non-urgent appointments being postponed. There is some evidence of potentially harmful consequences of these measures such as reductions in vaccination coverage compared to the same period in previous years. ${ }^{20,21}$

1. Department of Pediatrics. Hospital Beatriz Ângelo. Loures. Portugal.

$\triangle$ Autor correspondente: Mariana Poppe. mariana.cotrim.figueiredo@hbeatrizangelo.pt

Recebido: 07 de setembro de 2020 - Aceite: 05 de março de 2021 - First published: 26 de março de 2021 - Online issue published: 03 de maio de 2021

Copyright $\odot$ Ordem dos Médicos 2021 
Confinement in the household for a long period of time while being deprived from school, outdoor activities and contact with family-members and friends, has been challenging for children and their parents during the pandemic. The psychological, social and physical consequences due to social distancing are yet to be determined. ${ }^{22-24}$

This study aims to describe the impact of the pandemic on the use of healthcare services by the pediatric population and to assess the perspective of parents regarding the consequences for their children's health and wellbeing.

\section{MATERIAL AND METHODS}

We conducted a cross-sectional study, with data being collected through an anonymous online survey on social media. The survey consisted of an original non-validated questionnaire. Only fully completed surveys could be submitted, and participants could quit at any time. The survey was available for submission between the $1^{\text {st }}$ of May and the $17^{\text {th }}$ of May 2020, the day before the official reopening of kindergartens in Portugal after the first lockdown.

We accepted responses from parents with at least one child or adolescent ( 0 to 17 years and 364 days old) living in Portugal. Parents were asked to answer questions of mixed type (quantitative and qualitative), including multiple choice questions, dropdown questions, Likert scales and short-answer questions, concerning the period between the official school closure by the Portuguese government (March $16^{\text {th }}$ ) and the day of the submission of the survey.

Socio-demographic characterization included the child's district of residence, nationality, and age, as well as the maternal and paternal ages and educational level.

We collected information regarding the use of healthcare services during the COVID-19 pandemic, namely symptoms presented by the child (fever, cough, dyspnea, nausea or vomiting, diarrhea, otalgia, odynophagia, headache, urinary complaints, injuries following trauma, others), if he/she was taken to an emergency department (ED), whether the parents' choice of postponing or not visiting the ED would have been different if there was no pandemic and the number of hospital admissions and invasive medical interventions performed on the child (blood drawing for testing, intravenous or intramuscular medication, surgical procedure, others) during the stated period.

Pandemic-related information was gathered by assessing whether the child was part of a high-risk group for COVID-19 according to the guidelines of the Portuguese Directorate-General of Health ${ }^{25}$ and complemented by the local hospital's criteria (newborn, prematurity, asthma, bronchopulmonary dysplasia, diabetes, heart failure, chronic liver disease, chronic kidney disease, active malignant disease, inflammatory bowel disease, sickle cell disease, pharmacological immunosuppression, institutionalized child), and parental degree of concern of their child contracting the virus in a Likert scale from 1 (not at all concerned) to 5 (extremely concerned).

Consequences of COVID-19 on the child's health and access to medical care were assessed through questions concerning the attendance of scheduled medical appointments, vaccinations of the national immunization program and neonatal metabolic screening (options being no scheduling, carried out in person, conducted virtually, cancelled/ postponed by the family, cancelled/postponed by the healthcare institution or doctor), as well as the parental perception of negative consequences of the pandemic on their child's health on a Likert scale from 1 (strongly disagree) to 5 (strongly agree), complemented by a non-mandatory question characterizing the negative consequences observed. All other questions in the survey required a mandatory response.

We analyzed the data using frequencies and percentages for categorical variables. Counts and percentages were used to describe survey participants. Median values and interquartile range were reported for quantitative variables. Significant associations were evaluated by applying the Pearson's chi-squared test $\left(\chi^{2}\right)$, Mann-Whitney U-test $(U)$, Kruskal-Wallis test $(\mathrm{H})$ and the Spearman's correlation coefficient (rs) when appropriate, using SPSS $20^{\circledR}$. Significance for all the results was defined as $p<0.05$.

The study was approved by the Ethics Commitee of Hospital Beatriz Ângelo.

\section{RESULTS}

We obtained 12390 responses to the survey, regarding 19745 children. No participants were excluded from the study.

Socio-demographic characteristics of the participants are depicted in Table 1. The mean age of children in the study was 6.29 years $(S D=4.84)$.

As far as the usage of healthcare services during the pandemic is concerned, $20.6 \%$ of parents reported that at least one of their children was ill during the designated period. The most frequently reported symptoms were fever $(49.3 \%)$, cough $(34.9 \%)$ and odynophagia $(21.9 \%)$. Among the 2552 children that were reportedly ill, $31.8 \%$ were taken to an ED. When questioned, $33.9 \%$ of parents who visited the ED believed they would have gone earlier and $16.0 \%$ more often to the ED if it was not for the pandemic. Among the inquired whose children were ill and did not visit the ED, $22.8 \%$ admitted they would have visited the ED if there was no pandemic. The children's presentation of symptoms during the designated period was not significantly associated with the parental degree of concern towards the virus $(U=12338909.5, p>0.05)$. During the stated period, $1.0 \%$ of children in the survey were hospitalized and 3.2\% underwent invasive interventions. There were no significant differences in hospitalization rates or invasive interventions between children whose parents stated they would have come earlier (would have come earlier: $19.0 \%$; would not have come earlier: $21.9 \% ; \chi^{2}=2.184$, $p>0.05$ ) or more often (would have come more often: $21.5 \%$; would not have come more often: $21.4 \% ; \chi^{2}=0.001$, $p>0.05)$ to the ED in comparison with other children.

Concerning pandemic-related information, almost half of parents $(49.6 \%)$ stated that they were extremely concerned 
Table 1 - Socio-demographic characteristics of the participants

\begin{tabular}{|c|c|}
\hline Socio-demographic characteristics & $\begin{array}{c}n(\%) \text { of } \\
\text { respondents } \\
(n=12390)\end{array}$ \\
\hline \multicolumn{2}{|l|}{ District of residence } \\
\hline Aveiro & $332(2.7)$ \\
\hline Beja & $120(1.0)$ \\
\hline Braga & $821(6.6)$ \\
\hline Bragança & $49(0.4)$ \\
\hline Castelo Branco & $84(0.7)$ \\
\hline Coimbra & $306(2.5)$ \\
\hline Évora & $145(3.4)$ \\
\hline Faro & $416(3.4)$ \\
\hline Guarda & $62(0.5)$ \\
\hline Leiria & $305(2.5)$ \\
\hline Lisboa & $6207(50.1)$ \\
\hline Portalegre & $68(0.5)$ \\
\hline Porto & $1240(10.0)$ \\
\hline Santarém & $321(2.6)$ \\
\hline Setúbal & $1381(11.1)$ \\
\hline Viana do Castelo & $101(0.8)$ \\
\hline Vila Real & $64(0.5)$ \\
\hline Viseu & $178(1.4)$ \\
\hline Região autónoma dos Açores & $58(0.5)$ \\
\hline Região autónoma da Madeira & $131(1.1)$ \\
\hline \multicolumn{2}{|l|}{ Age of children } \\
\hline $0-2$ years & $5413(27.4)$ \\
\hline $3-6$ years & $5963(30.2)$ \\
\hline 7 - 11 years & $4831(24.5)$ \\
\hline $12-17$ years & $3538(17.9)$ \\
\hline \multicolumn{2}{|l|}{ Nationality of chidren } \\
\hline Portuguese & $12240(98.8)$ \\
\hline Other nationalities & $150(1.2)$ \\
\hline \multicolumn{2}{|l|}{ Maternal age } \\
\hline$<20$ years & $14(0.1)$ \\
\hline $20-29$ years & $1136(9.2)$ \\
\hline 30 - 39 years & $6360(51.3)$ \\
\hline $40-49$ years & $4421(35.7)$ \\
\hline$>50$ years & $444(3.6)$ \\
\hline NA & $15(0.1)$ \\
\hline \multicolumn{2}{|l|}{ Paternal age } \\
\hline$<20$ years & $1(0.0)$ \\
\hline $20-29$ years & $678(5.5)$ \\
\hline 30 - 39 years & $5475(44.2)$ \\
\hline $40-49$ years & $5071(40.9)$ \\
\hline$>50$ years & $1115(8.9)$ \\
\hline NA & $50(0.4)$ \\
\hline \multicolumn{2}{|l|}{ Maternal educational level } \\
\hline Primary school ( $1^{\text {st }}$ to $9^{\text {th }}$ grade) & $776(6.2)$ \\
\hline Secondary school ( $10^{\text {th }}$ to $12^{\text {th }}$ grade $)$ & $2293(18.5)$ \\
\hline Bachelor's degree or equivalent & $6846(55.3)$ \\
\hline Master's or Doctoral degree & $2475(20.0)$ \\
\hline \multicolumn{2}{|l|}{ Paternal educational level } \\
\hline Primary school ( $1^{\text {st }}-9^{\text {th }}$ grade $)$ & $2020(16.2)$ \\
\hline Secondary school $\left(10^{\text {th }}-12^{\text {th }}\right.$ grade $)$ & $3066(24.7)$ \\
\hline Bachelor's degree or equivalent & $5436(43.9)$ \\
\hline Master's or Doctoral degree & $1868(15.1)$ \\
\hline
\end{tabular}

(5 on the Likert scale) with the possibility of their child contracting the novel coronavirus (Fig. 1). Only $1.4 \%$ of respondents considered not to be to be concerned at all (1 on the Likert scale). Regarding the high-risk groups for COVID-19, $18.1 \%$ of children in our study were included in at least one of the groups, mainly due to asthma $(9.6 \%)$, followed by prematurity $(5.1 \%)$ and being newborn $(1.8 \%)$. During the designated period, children in a high-risk group presented with symptoms significantly more often compared to other children but did not attend the ED in significantly higher rates (Table 2). There was a significant association between belonging to a high-risk group and undergoing an invasive intervention or hospitalization (Table 2), with the odds being 3.44 times higher if the child had a risk factor compared to if he or she did not. Being included in a high-risk group was also significantly associated with a higher level of parental concern for their child contracting the virus (high-risk group: $\operatorname{Mdn}=5.00, I Q R=4.00-5.00$; no risk group: $M d n=4.00$, IQR = $3.00-5.00 ; U=9640774, p<0.001)$.

Regarding the consequences of COVID-19 on children's health and access to medical care, $48.3 \%$ of responders had a medical appointment previously scheduled for their child during the stated period. Of these 5984 scheduled appointments, $21.7 \%$ were carried out in person, $10.9 \%$ were conducted virtually (e.g., by telephone), $13.3 \%$ were cancelled at the request of the family, while $54.2 \%$ of appointments did not take place due to postponement or cancellation by the healthcare institution or doctor (Table 3). Parents' perception of a negative impact of the pandemic on their child was significantly impacted by the way medical appointments were conducted during this period $[\mathrm{H}(3)=40.334$, $p<0.01]$. Compared to when consultations were carried out in person, there was no significant difference in parental perception when they were cancelled by the family itself ( $U$ = 494 987.5, $p>0.05)$. However, when appointments were conducted virtually (virtual appointments: $\mathrm{Mdn}=2.00, \mathrm{IQR}$ $1.00-3.00$; appointments in person: $\mathrm{Mdn}=1.00, \mathrm{IQR}=$ 1.00 - 3.00; $U=389571.5, p<0.01$ ) or cancelled/postponed by the healthcare institution (appointments cancelled by healthcare institution: $M d n=2.00, I Q R 1.00-3.00$; appointments in person: $M d n=1.00, I Q R=1.00-3.00 ; U=1$ $874389, p<0.001$ ), the parental perception of a negative impact was significantly higher.

Concerning the vaccination appointments scheduled for vaccines included in the national immunization program, $22.2 \%$ (2747 children) had a vaccine administration scheduled during the designated period. While $78.4 \%$ were vaccinated according to plan, $21.6 \%$ (594 children) missed their vaccination $-11.6 \%$ due to family preference and $10.0 \%$ due to postponement or cancellation by the healthcare institution (Table 3).

The neonatal metabolic screening (heel prick test) was planned for $2.9 \%$ of children included in the survey, $1.4 \%$ of whom did not take place (five newborns) - one of them by choice of the family and four because of cancellation by the healthcare institution (Table 3).

Nearly half of parents $(48.7 \%)$ strongly disagreed that 
'Indicate your degree of concern regarding the possibility of your child contracting the novel coronavirus'

\begin{tabular}{|c|c|c|c|}
\hline ஓ̊ & $17.9 \%$ & $25.8 \%$ & $49.6 \%$ \\
\hline
\end{tabular}

\begin{abstract}
$\square$ Not at all concerned $\quad \square$ Slightly concerned $\quad \square$ Somewhat concerned
Moderately concerned

Extremely concerned
\end{abstract}

Figure 1 - Results of a Likert scale question used in the survey

the social distancing imposed by the pandemic affected their children's' health negatively (1 on the Likert scale), while only $4.4 \%$ strongly agreed there were negative health consequences ( 5 on the Likert scale). When asked to characterize these consequences in a non-mandatory question, 2517 parents described the negative effects observed in their children. Parental concerns included psychological consequences $(47.2 \%)$ such as anxiety, the most reported negative outcome (417 children), as well as behavioral and emotional changes; social consequences (33.6\%) comprising social isolation, decreased outdoor time and increased screen-time; health related issues $(27.0 \%)$, namely the loss of medical appointments and therapies considered essential; and physical health $(20.6 \%)$ including reduction of physical activity, weight increase and changes in eating and sleeping habits. There was a significant positive correlation between parental degree of concern towards the virus and the conviction of the pandemic and social distancing measures having a negative impact in their children's health ( $\mathrm{rs}=$ $0.054, p<0.001)$.

\section{DISCUSSION}

This study aims to describe the consequences of the COVID-19 pandemic on children's health and use of medical care in Portugal. We gathered information concerning around $1 \%$ of the Portuguese pediatric population, according to the national data of 2019. ${ }^{26}$

The COVID-19 pandemic contributed to changes in health-behaviors of the pediatric population including a re- duction in the use of healthcare services, as one can see by the rate of parents in our study who claim they would have visited the ED earlier, more often, or instead of other medical services for their children's symptoms if there was no pandemic. Changes in access to healthcare can also be demonstrated by the reduction of visits to the ED observed in several countries. ${ }^{9,12,16,17,19}$ The quasi simultaneous beginning of the pandemic with the decrease of ED visits seems to underline the association between the two events. ${ }^{9}$ Multiple factors seem to be involved in this change in the pattern of ED use. On one hand, children confined in the household tend to develop less acute infections and traumatic injuries compared to when contacting with other children in school and extracurricular activities. 9,12 The natural reduction in the reasons that motivate visits to the ED is not outbalanced by children with COVID-19 seeking medical care, since most of them have mild symptoms and are treated at home, with no need for hospital admission. ${ }^{5,27}$ Nevertheless, socially isolated children continue to get ill with occasional acute infections, trauma and acute presentations or exacerbations of chronic conditions, which might lead to the need for medical observation. Parental concern about their children being exposed to COVID-19, reported to be extremely high in almost half of the parents in this study, might contribute to the reluctance of bringing their children to an ED, as has been suggested by other studies. ${ }^{9,12,15}$ Some authors have pointed out the fear of "bothering the doctor" who is in the front line against COVID-19 as well as the fear of overburdening the healthcare system as an additional obstacle for

Table 2 - Comparison between children who belong to a high-risk group and children who do not

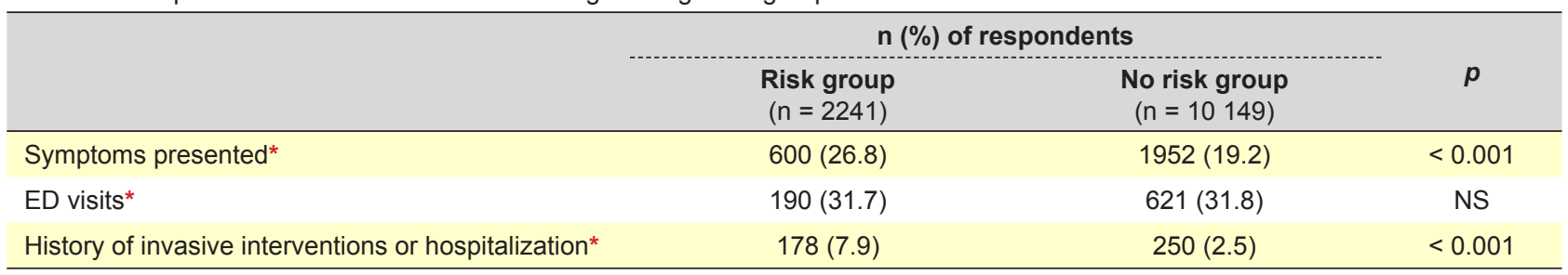

ED: emergency department; NS: not significant. *Presented as percentage, statistical analysis using Pearson's chi-squared test.

Table 3 - Outcome of scheduled medical appointments, vaccinations, and neonatal screenings

\begin{tabular}{|c|c|c|c|c|}
\hline \multirow[b]{2}{*}{ Scheduled appointments } & \multicolumn{4}{|c|}{$\mathrm{n}(\%)$ of respondents } \\
\hline & $\begin{array}{l}\text { Carried out } \\
\text { in person }\end{array}$ & $\begin{array}{l}\text { Carried out } \\
\text { virtually }\end{array}$ & $\begin{array}{l}\text { Cancelled/ postponed } \\
\text { by the family }\end{array}$ & $\begin{array}{l}\text { Cancelled/ postponed } \\
\text { by the healthcare institution }\end{array}$ \\
\hline $\begin{array}{l}\text { Vaccination } \\
(n=2747)\end{array}$ & $2153(78.4)$ & - & $320(11.6)$ & $274(10.0)$ \\
\hline $\begin{array}{l}\text { Neonatal screening } \\
\qquad(n=357)\end{array}$ & $352(98.6)$ & - & $1(0.3)$ & $4(1.1)$ \\
\hline
\end{tabular}


seeking medical care. ${ }^{10}$ Reports show that the delayed access to medical care has led to negative consequences in children's health, including fatal outcomes. ${ }^{12,13} \mathrm{~A}$ recently published study also showed that the decreased access to healthcare was one of the contributing factors to the excess mortality rates reported in the Portuguese population since the beginning of the pandemic, although the group under 55 years old did not contribute to the observed increase. ${ }^{15}$ Our study did not show a significant association between parents who opted to postpone or not visit the ED and negative health consequences such as increased number of invasive interventions, hospital admissions, or fatal outcomes. This might suggest that, apart from all the explanations above, there is a baseline overuse of emergency care in non-pandemic times and that children's symptoms could be handled by other healthcare services, namely the primary care setting. This is supported by the fact that Portugal is the country with the highest use of emergency services per capita in the Organization for Economic Cooperation and Development (OECD), ${ }^{28}$ representing significant numbers of inadequate use of this resource. ${ }^{9}$ Nevertheless, the potential danger of delayed access to medical care should not be overlooked and could impact the health of pediatric populations in both the short and long-term.

Regarding the postponement or cancellation of nonurgent medical appointments, our study shows that most scheduled consultations did not take place during the designated period, mainly by government-imposed measures or decisions from healthcare providers. A major concern is that the reduction of preventive medical care might be detrimental for non-COVID patients, especially those with chronic diseases or belonging to vulnerable groups. ${ }^{29}$ In the long term, this collateral effect of the pandemic may lead to a rise in hospital admissions, healthcare-costs and contribute to the overload of healthcare facilities already crowded with COVID-patients. ${ }^{29}$ The significant association between medical appointments either carried out virtually or cancelled/postponed by healthcare services and parental perception of negative outcomes for their children underlines how the decision of how consultations are carried out could have a damaging impact on children's health and contribute further to parental fear of accessing healthcare, thus aggravating the reluctance in seeking medical assistance.

The decline in vaccination coverage during the pandemic is particularly important, with $21.6 \%$ of the scheduled vaccinations in our study being missed. During the month of April 2020, the vaccine administrations within the Portuguese national immunization program dropped to almost half the numbers of the previous year ${ }^{20}$ and data from several countries points to similar potentially harmful health behaviors, ${ }^{21,23}$ posing an increased risk of outbreaks of vaccine-preventable diseases. Considering neonatal metabolic screening, which intends to diagnose genetic diseases that benefit from early treatment, five tests in our study were missed, representing $1.4 \%$ of newborns in the study. According to the national data available, neonatal screening coverage in Portugal reaches $99.5 \%,{ }^{30}$ meaning the rate in our study poses a 2.8-fold increase in missed screenings.

Looking at the consequences of the COVID-19 pandemic on the health and wellbeing of children and adolescents, it becomes clear that a major threat for this population might lie beyond the clinical aspects of the pandemic. ${ }^{31}$ Parents in our study expressed several apprehensions in different areas of development of their children.

Countries worldwide have opted for school closures in order to reduce the transmission of the virus, although the effectiveness of this measure is not entirely clear. ${ }^{32}$ The closure of schools creates enormous challenges, starting with restrictions to the learning process for children all over the world. It also seems to pose a risk of aggravating the widening gap between children of high and low-income families, since poorer households might have limited resources such as computers or internet access to maintain online learning provided by some schools. ${ }^{23}$ Furthermore, some of these children rely on school meals for adequate nutrition or washing facilities for adequate hygiene. ${ }^{31}$ Other vulnerable groups especially affected by school closures include children with special educational needs and disabilities, to whom the lack of daily routines and appropriate stimuli can cause significant disruption to the wellbeing. The fact that these children are missing their medical appointments and therapy sessions constitutes a risk for setbacks in their development and progression of essential skills, ${ }^{22}$ and is a worry expressed by parents in our study.

Other outcomes reported by parents in our study have to do with the reduction of physical activity, increased weight, change in eating and sleeping habits as well as increased sedentary activities and screen-time, as has been described by other authors. ${ }^{24,31}$ The disruption of daily routines and the acquired sedentary behaviors might exacerbate childhood obesity, ${ }^{33,34}$ and the establishment of unhealthy habits in the long-term can compromise future cardiovascular and musculoskeletal health. ${ }^{31}$ Furthermore, physical activity contributes positively to mental health, and can be used as a coping mechanism when facing challenges such as pandemics, leading to reduction of anxiety and depression levels. ${ }^{34-36}$

Mental health seems to be a major concern for parents in our study, with anxiety being the most frequently expressed preoccupation. Reasons for anxiety during pandemics include the fear of infection, frustration, boredom, lack of interaction with family members and friends, increased incidence and severity of domestic violence, abuse, and child neglect, ${ }^{22,23}$ and the aforementioned school closures and reduction of physical activity. ${ }^{37}$ Facing a worldwide pandemic with extraordinary and sudden routine disruptions poses a challenge for children's resilience and coping mechanisms, and yet mental health seems to be at risk of being overlooked and not prioritized. ${ }^{38}$ When comparing post-traumatic stress responses in children who were quarantined during pandemics and others who were not, the mean scores for post-traumatic stress disorders were found to be four times higher in children who were quarantined. ${ }^{39}$ The long-term effects of these unprecedented social distancing measures 
on children's mental health is yet to be determined, and the possible psychological costs should be taken into consideration when imposing these measures. ${ }^{22,37}$

There are some limitations to our study. Information was gathered via parental recall, which might introduce bias for various reasons, including subjective perception and accuracy of memory. The fact that parents with more than one child filled a single questionnaire for all their children might hinder the analysis of data, especially when concerning vaccination coverage. By collecting data through an online survey, our inquiry might not have reached the social fringes, since internet access is not equally accessible to all social strata. Additionally, the dissemination of the survey through social media poses a risk of biased selection of participants, excluding non-users of those networks. Moreover, Portuguese districts were not portrayed in a representative proportion, with over-representation of major cities. The fact that the study was conducted for a brief period potentially biased the responses according to the pandemic-related events during the designated period.

\section{CONCLUSION}

In summary, the impact of the COVID-19 pandemic on children's health includes a change in the use of healthcare services as well as psychological, social, and physical consequences pointed out by parents that should not be overlooked. The future course of the pandemic is uncertain, as is the reorganization of medical services to face this challenge. Future studies to be carried out will be necessary in order to better understand the consequences of decreased ED visits, allowing for interventions to address potentially negative health outcomes. Efforts should be made to clearly communicate the recommendation of not postponing urgent medical evaluations to patients. Simultaneously,

\section{REFERENCES}

1. World Health Organization. WHO Director-General's opening remarks at the media briefing on COVID-19 - 11 March 2020. [accessed 2020 May 13]. Available from: https://www.who.int/dg/speeches/detail/whodirector-general-s-opening-remarks-at-the-media-briefing-on-covid-19--11-march-2020.

2. Direcção Geral da Saúde. Relatório de situação caracterização demográfica dos casos confirmados. [accessed 2020 Jun 02]. Available from: https://covid19.min-saude.pt/.

3. Zimmermann P, Curtis N. Coronavirus infections in children including COVID-19: an overview of the epidemiology, clinical features, diagnosis, treatment and prevention options in children. Pediatr Infect Dis J. 2020;39:355-68.

4. Brodin P. Why is COVID-19 so mild in children? Acta Paediatr. 2020;109:1082-3.

5. Dong Y, Mo X, Hu Y, Qi X, Jiang F, Jiang Z, et al. Epidemiology of COVID-19 among children in China. Pediatrics. 2020;145:20200702.

6. Castagnoli R, Votto M, Licari A, Brambilla I, Bruno R, Perlini S, et al. Severe acute respiratory syndrome coronavirus 2 (SARS-CoV-2) infection in children and adolescents: a systematic review. JAMA Pediatr. 2020;174:882-9.

7. Lu X, Zhang L, Du H, Zhang J, Li Y, Qu J, et al. SARS-CoV-2 infection in children. N Engl J Med. 2020;382:1663-5.

8. Zachariah P, Johnson CL, Halabi KC, Ahn D, Sen Al, Fischer A, et al. Epidemiology, clinical features, and disease severity in patients with coronavirus disease 2019 (COVID-19) in a dhildren's hospital in New York City, New York. JAMA Pediatr. 2020;e202430.

9. Santana R, Sousa JS, Soares P, Lopes S, Boto P, Rocha JV. The safety conditions must be ensured in healthcare facilities to minimize the risk of exposure to the novel coronavirus to a minimum, protecting both patients and healthcare workers and restoring confidence in seeking medical care. It should be a public health priority to compel parents to vaccinate their children and create pathways to allow vaccination without risk of COVID-19 exposure. Psychological, social, and physical consequences for children and adolescents risk being overlooked during the pandemic and should be assessed in further depth in order to set strategies to minimize potentially negative outcomes, especially in the most vulnerable populations.

\section{PROTECTION OF HUMANS AND ANIMALS}

The authors declare that the procedures were followed according to the regulations established by the Clinical Research and Ethics Committee of Hospital Beatriz Ângelo and by the Clinical Research and Ethics Committee and to the Helsinki Declaration of the World Medical Association updated in 2013.

\section{DATA CONFIDENCIALITY}

The authors declare having followed the protocols in use at their working centre regarding patients' data publication.

\section{CONFLICTS OF INTEREST}

The authors have no conflicts of interest to declare.

\section{FUNDING SOURCES}

This research received no specific grant from any funding agency in the public, commercial, or not-for-profit sectors.

demand for hospital emergency services: trends during the first month of COVID-19 response. Port J Public Heal. 2020;38:30-6.

10. Rosenbaum L. The untold toll - the pandemic's effects on patients without COVID-19. N Engl J Med. 2020;382:2368-71.

11. Garcia S, Albaghdadi MS, Meraj PM, Schmidt C, Garberich R, Jaffer FA, et al. Reduction in ST-segment elevation cardiac catheterization laboratory activations in the United States during COVID-19 pandemic. J Am Coll Cardiol. 2020;75:2871-2.

12. Lazzerini M, Barbi E, Apicella A, Marchetti F, Cardinale F, Trobia G. Delayed access or provision of care in Italy resulting from fear of COVID-19. Lancet Child Adolesc Health. 2020;4:e10-1.

13. Ding YY, Ramakrishna S, Long AH, Phillips CA, Montiel-Esparza R, Diorio CJ, et al. Delayed cancer diagnoses and high mortality in children during the COVID-19 pandemic. Pediatr Blood Cancer. 2020;e28427.

14. Snapiri O, Danziger CR, Krause I, Kravarusic D, Yulevich A, Balla U, et al. Delayed diagnosis of paediatric appendicitis during the COVID-19 pandemic. Acta Paediatr. 2020;109:1672-6.

15. Nogueira PJ, Nobre MD, Nicola PJ, Furtado C, Vaz Carneiro A. Excess mortality estimation during the COVID-19 pandemic: preliminary data from Portugal. Acta Med Port. 2020;33:376-83.

16. Metzler B, Siostrzonek P, Binder RK, Bauer A, Reinstadler SJ. Decline of acute coronary syndrome admissions in Austria since the outbreak of COVID-19: the pandemic response causes cardiac collateral damage. Eur Heart J. 2020;41:1852-3.

17. Wong LE, Hawkins JE, Langness S, Murrell KL, Iris P, Sammann A. Where are all the patients? Addressing COVID-19 fear to encourage sick patients to seek emergency care. NEJM Catal. 2020;1-12. doi: 
10.1056/CAT.20.0193.

18. Thornton J. COVID-19: A\&E visits in England fall by $25 \%$ in week after lockdown. BMJ. 2020;369:m1401.

19. Hartnett KP, Kite-Powell A, DeVies J, Coletta MA, Boehmer TK, Adjemian $\mathrm{J}$, et al. Impact of the COVID-19 pandemic on emergency department visits - United States, January 1, 2019-May 30, 2020. MMWR Morb Mortal Wkly Rep. 2020;69:699-704.

20. Covid19.min-saude.pt. Subdiretor-Geral da Saúde reforça o apelo à vacinação - COVID-19. [accessed 2020 May 08]. Available from: https:// covid19.min-saude.pt/subdiretor-geral-da-saude-reforca-o-apelo-avacinacao/.

21. Santoli JM, Lindley MC, DeSilva MB, Kharbanda EO, Daley MF, Galloway L, et al. Effects of the COVID-19 pandemic on routine pediatric vaccine ordering and administration - United States, 2020. MMWR Morb Mortal Wkly Rep. 2020;69:591-3.

22. Lee J. Mental health effects of school closures during COVID-19. Lancet Child Adolesc Heal. 2020;4:421

23. Crawley E, Loades M, Feder G, Logan S, Redwood S, Macleod J. Wider collateral damage to children in the UK because of the social distancing measures designed to reduce the impact of COVID-19 in adults. BMJ Paediatr Open. 2020;4:e000701.

24. Pecoraro L, Dalle Carbonare L, De Franceschi L, Piacentini G, Pietrobelli A. The psychophysical impact that COVID-19 has on children must not be underestimated. Acta Paediatr. 2020;109:1679-80.

25. Direcção Geral da Saúde. Quem está em risco? [accessed 2020 May 02]. Available from: https://covid19.min-saude.pt/quem-esta-em-risco/.

26. Pordata.pt. População residente, média anual: total e por grupo etário. [accessed 2020 Apr 28]. Available from: https://www.pordata.pt/ Portugal/População+residente++média+anual+total+e+por+grupo+etár io-10.

27. Bialek S, Gierke R, Hughes M, McNamara LA, Pilishvili T, Skoff T. Coronavirus disease 2019 in children - United States, February 12April 2, 2020. MMWR Morb Mortal Wkly Rep. 2020;69:422-6.

28. Berchet $C$. Emergency care services: trends, drivers and interventions to manage the demand. OECD Heal Work Pap. $2015 ; 83$.

29. Domeyer $P$, Katsari $V$, Mariolis A. Chronic non-communicable diseases: a sacrifice on the altar of COVID-19? Br J Gen Pract. 2020;70:281.

30. Lusa.pt. Dados do "teste do pezinho" apontam para mais cerca de 500 nascimentos em 2019. [accessed 2020 May 27]. Available from: https:// www.lusa.pt/article/NaV_PENgKAkWbL9aaWp06zMSZM5iuSI1/dadosdo-teste-do-pezinho-apontam-para-mais-cerca-de-500-nascimentosem-2019.

31. The Lancet Child Adolescent Health. Pandemic school closures: risks and opportunities. Lancet Child Adolesc Health. 2020;4:341.

32. Viner RM, Russell SJ, Croker H, Packer J, Ward J, Stansfield C, et al. School closure and management practices during coronavirus outbreaks including COVID-19: a rapid systematic review. Lancet Child Adolesc Health. 2020;4:397-404.

33. Rundle AG, Park Y, Herbstman JB, Kinsey EW, Wang YC. COVID-19related school closings and risk of weight gain among children. Obesity. 2020;28:1008-9.

34. Margaritis I, Houdart S, El Ouadrhiri Y, Bigard X, Vuillemin A, Duché P. How to deal with COVID-19 epidemic-related lockdown physical inactivity and sedentary increase in youth? Adaptation of Anses' benchmarks. Arch Public Health. 2020;78:52.

35. World Health Organization. Global recommendations on physical activity for health. Geneve: WHO; 2010.

36. Shahidi SH, Stewart Williams J, Hassani F. Physical activity during COVID-19 quarantine. Acta Paediatr. 2020;109:2147-8.

37. Brooks SK, Webster RK, Smith LE, Woodland L, Wesseley S, Greenberg $\mathrm{N}$, et al. The psychological impact of quarantine and how to reduce it: rapid review of the evidence. Lancet. 2020;395:912-20.

38. Danese A, Smith P, Chitsabesan P, Dubicka B. Child and adolescent mental health amidst emergencies and disasters. $\mathrm{Br} \mathrm{J}$ Psychiatry. 2020;216:159-62.

39. Sprang G, Silman M. Posttraumatic stress disorder in parents and youth after health-related disasters. Disaster Med Public Health Prep. 2013;7:105-10. 